\title{
Managing a sustainable tourism destination
}

\author{
A. Panić ${ }^{1}$, M. Koščak ${ }^{2}$ and B. Pavlakovič ${ }^{3}$ \\ Faculty of tourism, University of Maribor
}

\begin{abstract}
Likewise, any other industry, tourism faces modifications which are stimulated with technological, social and environmental changes. New concepts of tourism have emerged that understand tourism on a different, more social-responsible and educative way. Therefore, tourism developed new branches which emphasize socio-ecological awareness, clear goals and more comprehensive approach in tourism management. Tourists who are interested in this kind of tourism experience request high level of sustainable and responsible attention, better off for residents and promotion of local uniqueness, such as local culture, history, cuisine, events, etc. Therefore, there is a need for well-organized tourism management which will gather all of these requirements and convert them to a unique tourism offer. There are many successful practices, not only in Europe but overseas, which could use as an example of good and sustainable tourism management. On the other hand, Belgrade, the capital of Serbia, struggles to achieve this kind of tourism attractiveness. Many complains on city's tourism offer are persistent, as well as critics regarding the sustainable and responsible standards and cleanliness of the city. Because of that, this paper will provide overlook on current circumstances in Belgrade and provide examples and suggestions on steps which need to be undertaken in order to make better environment for both tourists and local society.
\end{abstract}

Keywords: Belgrade, tourism, development, sustainability, sustainable tourism

\section{Introduction}

With the massive development and popularization of tourism, many countries quickly realized the numerous benefits of this industry. These benefits were primarily reflected in the fact that the development of tourism brings with it a greater economic prosperity. In the middle of the twentieth century, a tourist concept is being implemented which stimulates exclusively economic goals, that is to achieve as much profit as possible from tourism. Strengthening and spreading of traditional mass tourism in that period resulted in real danger of devastation and disappearance of resources and authenticity of tourist destinations. Motivated by this problem, at the end of the twentieth century, individual countries began to advocate more for conserving natural resources, preserving the eco-system, which later expanded to social and cultural aspects and created a completely new concept of sustainable tourism. The idea of sustainable tourism involves the use of local resources, but in a responsible and sustainable way, as well as the 
International Conference on Research in Management \& Economics

Serbia | Belgrade | December 15-17, 2018

promotion of local specialties and allocations of mass tourism character. In addition, this also involves the involvement of the local tourist community, directly or indirectly, in order to contribute to the development of its tourism area, while achieving economic well-being. In addition, one of the fundamental objectives of this concept is ecological awareness, which means that the preservation of natural resources is one of the priorities.

This concept began to expand rapidly across the European continent, but it is still not developed or developed at all in some countries, especially Eastern Europe, which includes Serbia. Considering its position, numerous natural and social resources, Serbia certainly has the potential to develop this concept of tourism. Belgrade can have significant economic and cultural benefits from tourism. With a good strategy and a sustainable way of organizing and developing this destination, Belgrade can create positive effects for the improvement of all segments of the tourist offer, better positioning in the European and regional tourist market, thus creating the possibility for opening new jobs (primarily in the catering industry) and making profits for a long period. In addition, such a concept would have positive effects on the local population. In addition to these new jobs, more healthy living conditions would be created. This is particularly important in large cities where there is a large fluctuation of traffic and where exhaust gases damage the environment. Finally, a successfully implemented and applied concept could serve as an example to other cities in the country. In this way, the social and natural resources of the country would be used in a sustainable way on a larger scale.

\section{Sustainable and Responsible Tourism}

With its development in recent years in addition to economic and social importance, tourism has played a significant role in the context of promotion and implementation of plans and systems for sustainable development. According to the UNWTO (2017), the number of trips in 2015 will exceed one billion, according to their forecasts by 2020, this figure will also exceed 1.5 billion tourists annually throughout the world. Despite the many security challenges that it has faced, Europe has attracted more than half of world's tourists in 2015 (608 million). This shows that interest in the European continent does not extinguish and that in the future, the number of tourists will continue to be very high. This further leads to a legitimate conclusion that despite the economic benefits, serious risks will arise in terms of endangering the environment, the well-being of the population and the preservation of the tourist potential and the attractiveness of the destination for a longer period, which endangers the entire tourism sector. The greatest dangers come from the continuing neglect of the environment and its significance, which is a consequence of poor organization and unplanned tourism management.

Up to half ' 80 . of the last century, the primary focus of the tourism industry was on economic profit - on direct, indirect and mulitifplicated economic effects, on the consumption of domestic 
International Conference on Research in Management \& Economics

Serbia | Belgrade | December 15-17, 2018

and foreign tourists and their impact on the country's economy. Such an approach has brought many condemnations and criticisms, primarily because of negligence towards society, but also to tourists themselves. First of all, an unacceptable treatment of the natural environment and a disreputable construction for tourist purposes. In addition to the destruction of space, there has also been a commercialization of cultural and historical heritage, as well as the loss of authenticity of the destination. Because of the loss of this authenticity, numerous destinations have also lost the interest of tourists to visit these towns (Bakić, 2010, pp. 24-25). Due to such practice and such development of tourism, there has been the development of "alternative forms of tourism", of "more humane", "healthier" and "responsible" tourism.

The concept of sustainable tourism development is a relatively young trend in the tourism industry and as such has not yet been applied in a larger scale. The United Nations Environment and Development Conference adopted the Agenda defining the Action Plan for a Sustainable Development Conference in Rio de Janeiro in 1992 (Krivošev, 2014, p. 50). However, due to its characteristics and the goal that this concept aims at and the idea it carries with it, it has become very popular and, on a scientific basis, highly desirable for studying and further upgrading. As such, it has been and remains the subject of numerous analyses and discussions from which various definitions and explanations of this concept emerged. Butler $(1999$, p.10) in his work cites several definitions, first of all Eber $(1992$, p. 3) which emphasizes that sustainable tourism is "tourism and appropriate infrastructure that: both now and in the future act within the natural capacities for regeneration and future productivity of natural resources; Recognizes the contribution that people and communities, customs and lifestyles give for a tourist experience; It acknowledges that people must have an equal share in the economic benefits of the local community and people in tourism areas."

Butler quotes the Countryside Commision $(1995$, p. 2) that focuses on the local economy: "A tourism that can sustain a local economy without damaging the environment on which it depends." Swartbrooke (1999, p. 13), to its definition of sustainable tourism comes through the emphasis on the importance of the economic, natural and social elements of the tourist system - "tourism that is economically viable, but which does not destroy the resources on which the future of tourism will depend, in particular the physical environment and social material of the local community." Similarly, Hetzer (1965, pp. 1-3), quoted in his work by Cheia (2013, p. 56), which claims that there are four most important factors, namely: "the smallest possible impact on nature and environment, respect for domestic (local) culture, greater benefits for the local population and greater satisfaction for tourists."

Taking into account all of this, we come to several major factors of sustainable development in tourism, such as (Vujić, 2011, p. 476):

- Tourists, who influence sustainability with their acts

- Tourism employees, who directly or indirectly influence sustainability 
International Conference on Research in Management \& Economics

Serbia | Belgrade | December 15-17, 2018

- Business entities in tourism, within basic and related activities

- Public services

- Local people

Despite different definitions, science has recognized and agreed on the core, or the main pillars of sustainable development. These are social, ecological (and cultural) and economical moments. It is therefore clear to define the goals of the concept of sustainable tourism development. First, through the protection of cultural and historical heritage and natural resources, the preservation of destination uniqueness this prolongs the length of local resources. Secondly, by including other industries and service activities, the tourist offer of the destination is enhanced. This primarily means that the local community, in a direct or indirect manner, is included in the tourist offer and with its goods or services additionally promote the local culture and the specificities of this destination. For example, by engaging local farmers tourists would have the opportunity to enjoy local products, which means that these producers are also indirectly (sometimes directly) included in the tourist offer. This can also define the third importance of this concept, which is the economic development of the local community. Namely, when the inclusion of other local producers and suppliers of goods and services, employment of new people in local tourist centres, generating money from the sale of tourist services and goods (such as souvenirs), leads to an increase in the economic well-being of the local community.

\section{SWOT Analysis}

To provide a better insight into Belgrade sustainable tourism situation, we have made a SWOT analysis of the city. In table 1 there are presented strengths and weaknesses of Belgrade, which will be explained next.

Table 1 - Strengths and Weaknesses of Belgrade

\begin{tabular}{|c|c|}
\hline Strengths & Weaknesses \\
\hline $\begin{array}{c}\text { Geographical location - the hub of road } \\
\text { and river corridors }\end{array}$ & $\begin{array}{r}\text { Lack of strategy for sustainable } \\
\text { destination development }\end{array}$ \\
\hline Climate characteristics & Traffic infrastructure \\
\hline $\begin{array}{c}\text { Accommodation capacities - price and } \\
\text { quality ratio versus competition in the } \\
\text { region }\end{array}$ & $\begin{array}{c}\text { Pollution of rivers, coastal areas and } \\
\text { green areas (ecology) }\end{array}$ \\
\hline $\begin{array}{l}\text { The most developed city in the } \\
\text { country }\end{array}$ & $\begin{array}{l}\text { Insufficient utilization of MICE } \\
\text { capacity }\end{array}$ \\
\hline
\end{tabular}


International Conference on Research in Management \& Economics Serbia | Belgrade | December 15-17, 2018

\begin{tabular}{|c|c|}
\hline $\begin{array}{l}\text { New national airline / connections } \\
\text { with numerous European and } \\
\text { international } \\
\text { destinations }\end{array}$ & Taxi transportation \\
\hline Rich cultural and historical heritage & \\
\hline Hospitality of the local population & \\
\hline
\end{tabular}

When we talk about the advantages that Belgrade has as a tourist destination, its position is in the first place. It has already been said that Belgrade is at the crossroads of two international waterways - the Danube and the Sava River, which allows it to generate the influx of tourists directly to its shores. Also, Belgrade is characterized by a positive climate, which contributes to tourism activities throughout the year. In almost all countries, the capital is also the most developed place in the country, so Serbia is no exception. This is supported by the fact that with the establishment of a new national airline and its networking with numerous destinations, as well as raising the quality of service at the airport, Belgrade has seen a significant increase in the number of tourists. In addition, Belgrade is rich in cultural and historical content, which may be interesting to tourists, given its history and the different cultures and people that have changed in this city. There is also the traditional cordiality and hospitality of the Serbian people, which leaves perhaps the strongest impression on the guests.

Large crowds, uncompleted bypass, an international corridor that passes through the urban part of the city, a lack of parking spaces, undeveloped metro links, create a major problem when traveling both tourists and the local population. The great problem of the capital, and which is especially important for the topic of this work, is ecology. In addition to official data and the European Commission's assessment, this is visible on rivers, coasts and green areas. Furthermore, Belgrade has only four 5-star hotels. For MICE tourism, which Belgrade aims to develop, this is an extremely small number. On the other hand, although the Strategy for Tourism has been adopted, there is still no clear definition of how Belgrade wants to develop tourism: MICE capacities are significant, as we have already analysed, however, it seems that the economic entities that have these capacities are left to promote their own capacities and attract interested clients. Next step in SWOT analysis was define opportunities and threats of Belgrade, which are presented in table 2.

Table 2 - Opportunities and Threats of Belgrade

\begin{tabular}{|c|c|}
\hline Opportunities & Threats \\
\hline Finalization of the project "Belgrade & $\begin{array}{c}\text { Unstable political and economic } \\
\text { Waterfront" }\end{array}$ \\
& $\begin{array}{c}\text { situation in the country and the } \\
\text { region }\end{array}$ \\
\hline
\end{tabular}


International Conference on Research in Management \& Economics Serbia | Belgrade | December 15-17, 2018

\begin{tabular}{|c|c|}
\hline $\begin{array}{l}\text { Promotion of Belgrade on the } \\
\text { international market }\end{array}$ & $\begin{array}{l}\text { A large number of terrorist attacks } \\
\text { across } \\
\text { Europe }\end{array}$ \\
\hline $\begin{array}{l}\text { Country's interest in the tourism } \\
\text { sector }\end{array}$ & City - break destinations in the region \\
\hline $\begin{array}{r}\text { Increase in the number of large hotel } \\
\text { chains }\end{array}$ & $\begin{array}{r}\text { Slow reconstruction of tourist } \\
\text { infrastructure }\end{array}$ \\
\hline $\begin{array}{r}\text { Investing in traffic and tourist } \\
\text { infrastructure }\end{array}$ & Global economic recession \\
\hline $\begin{array}{l}\text { Attracting foreign and domestic } \\
\text { investments into tourist facilities and } \\
\text { infrastructure }\end{array}$ & \\
\hline
\end{tabular}

Speaking about the opportunities of Belgrade to improve its position on the tourism market, we should mention the current biggest project in the country, which is "Belgrade Waterfront". Still, the finalization of this project needs to wait a lot longer because the total deadline for completing the entire project is planned for 30 years. Until then, Belgrade should make more use of international trade fairs, tourist rallies and all legitimate marketing assets in order to more effectively promote its tourist offer in the foreign market. In that, we should expect the help of the state that is investing more and more in the promotion of domestic tourism in recent years. As we have already pointed out, the arrival of new large hotel chains will be announced and the capacity for accommodation and the service of guests will be even more significant. In addition to investing efforts to bring foreign hotel chains, the state is also working to improve the transport infrastructure, and in this regard it is working on the completion of the bypass around Belgrade, which should significantly reduce crowds in the city. There should be a space for attracting ecologically-conscious tourists, which without the development of the concept of sustainable tourism and a clear strategy in this direction is not possible. Finally, another big chance is the influx of more passengers after reconstruction of the airport and the establishment of new lines. This will undoubtedly strengthen the existing connections, as well as open new markets in Europe as well as in the East and the West.

When we talk about the factors that pose a threat to the further development of tourism in Belgrade, there should be problematic and unstable economic and political situation in the country and the region mentioned in the first place. First of all, the low standard of living of citizens from most of the countries of the former Yugoslavia prevents higher flow of regional tourists. There is also a factor that burdens the political stability of the country, which is the issue of the southern Serbian province of Kosovo and Metohija. In addition, there are frequent verbal conflicts between the countries of the Balkan Peninsula, which have intensified with the onset of 
International Conference on Research in Management \& Economics Serbia | Belgrade | December 15-17, 2018

a migrant influx. All this affects tourists to choose Belgrade as the destination to visit. The aforementioned economic instability is certainly caused by a major recession that hit most of the planet in 2008. However, the last parameters give reasons for optimism, since there is a steady increase in tourists. Of course, if a similar situation would recur, it would drastically affect tourism in Belgrade. There is also a threat from the competition, primarily from the region. Far ahead of everyone in the region is Budapest, however, the increase in the number of tourists recorded by Belgrade is an indicator that tourists are increasingly choosing the Serbian capital for their vacation. When it comes to raising the quality of the tourist offer, it should be said that the reconstruction of the existing and the construction of a new tourist infrastructure must be quick and efficient. At a time when technology is constantly advancing, it is unacceptable that a tourist destination that wants to record a serious result of the tourism market, has an old and inadequate infrastructure. Finally, there was lately a growth of terrorist attacks. The attacks in Paris, Brussels, Nice, London, Manchester, Saint Petersburg and cities across Turkey has significantly influenced the reduction of travel and pitched fear among tourists from traveling. Belgrade and Serbia do not fall into high-risk areas, but given the large number of people from the Middle East passing through Belgrade, such a risk cannot be excluded or taken frivolous.

\section{Research and Analysis of current situation, plans and future activities for Sustainable Development of Tourist offer of Belgrade}

Empirical research of the current state of tourism in the city of Belgrade was performed by using semi-structured interviews as a research method. Interviews were conducted with responsible persons from different tourism sectors. The research was carried out in two relevant touristic subjects. First of all, the basic and most important part of the research process was carried out at the Tourist Organization of Belgrade (TOB) as the main organization for the promotion and planning of city tourism development. The purpose of the interview was to gather the necessary primary information on how this organization plans to further improve the city's tourist offer. Besides that, interview was also made at the tourist agency "Sabra" which helped to gain important information in the sphere of receptive tourism, as well as observations and impressions that foreign tourists carry from Belgrade. Finally, this helped to define the basic shortcomings in the current organization of the destination and based on that, through the benchmarking analysis with foreign example of good practice (the capital of Slovenia, Ljubljana and its concept "Green Ljubljana"), the best possible solutions are proposed for such defects. 
International Conference on Research in Management \& Economics

Serbia | Belgrade | December 15-17, 2018

\section{Analysis of the interviews}

Initially, the questions were related to the results of the tourism in 2017, from the aspect of the attendance, the recorded trends, and individual visits of foreign and domestic tourists. The largest number of registered foreign tourists, according to the data of the agency "Sabra", is from Asian countries, primarily from China and Taiwan. This fact confirms the thesis that Belgrade and Serbia are becoming more and more attractive to tourists from the Far East. The enormous potential that the Asian market brings with it moves the focus of receptive travel agencies into that part of the world. It is also expected to continue recording a positive trend in terms of tourists from the East in the coming years, especially according to the tourism campaign that targets this tourism market. In addition to Asian tourists, there is noticeable presence of tourist groups from Europe, primarily from Austria and Italy. However, according to the data of this travel agency, the smallest number of tourists comes from Germany. So far, in 2017, over a million overnight stays have been recorded and an increase of $12 \%$ over the previous year. According to a comprehensive survey conducted by TOB in 2016 , as many as $85 \%$ of the tourists surveyed feel safe in Belgrade When it comes to the city's most visited attractions, those are: Beli dvor, Kalemegdan, Skadarlija, the coastal area along the river tours (additional popularization and the visit of this part of the city is expected with the construction of the project "Belgrade Waterfront") Savamala (where tourists, among other things, go because of the re-popularization of karaoke as a form of entertainment), Cetinjska Street, the city center and Novi Beograd as a business and ambience unit.

According to TOB, most foreign tourists come to Belgrade from Turkey. Only in 2017 was growth of as many as $52 \%$ of Turkish tourists in Belgrade. The reason lies in the introduction of new direct flights from Istanbul, including low-cost companies. In addition, more and more Turkish companies in Serbia are also bringing an additional influx of Turkish citizens. What is a novelty is that Belgrade is recording a high growth trend when it comes to visiting tourists from Israel. As in the case of Turkey, a large number of direct flights, but also a growing number of business opportunities in the capital of Serbia, attracts people from Israel. What is even more interesting is, according to TOB, unlike most tourists who stay in Belgrade for up to 3 days, guests from Israel stay for up to 7 days. Bearing in mind their payment power, it is clear that Belgrade has a huge economic benefit from it. Motives for visiting are mostly the same, and according to the aforementioned research, the strongest impression that tourists bring from Belgrade are the kindness, hospitality of the citizens of Belgrade, as well as a very good atmosphere in the city. Speaking about the presence of domestic tourists visiting Belgrade, the situation began to improve since last year, when the Government of the Republic of Serbia, led by the Ministry of Trade, Tourism and Telecommunications, launched the action of sharing vouchers for holidays in Serbia. This action had a big echo, especially in the oldest population, and the participation of 
International Conference on Research in Management \& Economics

Serbia | Belgrade | December 15-17, 2018

domestic guests was very high. When it comes to utilizing the fact that Belgrade lies on two rivers, and that tourists have the opportunity to get to know Belgrade from another perspective, TOB makes a distinction between seeing a city from a river and a cruiser that sails to Belgrade via the international river route, most often across the Danube. Namely, TOB uses and promotes private companies that provide such services, and who perform tours when they collect enough number of interested ones. When it comes to the second category of tourist exploitation of the river, the number of consignments in the Belgrade port is increasing from year to year.

Research showed that the majority of people who visit Belgrade belong to the oldest group of people over 65 years of age. They also point out the hospitality, good and cheap food and atmosphere in the city as the biggest advantage of Belgrade. Even $83 \%$ of respondents said they were the first time in Belgrade and a large percentage expressed their desire to come again, but also to recommend Belgrade as a tourist destination to their friends, which is a confirmation of the good impression that from Belgrade are worn. When it comes to positive criticism of tourists, the most important ones are hospitality, delicious food, people who know the English language well, as well as good training and professional behaviour of tour guides. On the other hand, negative reviews are most often related to poor traffic infrastructure, ecology, insufficient info boards, souvenir shops, internet and Wi-Fi zones, undeveloped dock and lack of waste bins, shopping distance, as well as the need to provide better access to people with disabilities. In any case, there is room for improvement of services for tourists who are among the best paying and with the most free time.

The highest inflow of foreign tourists was recorded in the period from April to October. This is for all "city break" destinations, and so for Belgrade, the main period of the tourist season. It is interesting that the period during New Year's and Christmas holidays was not highlighted, although a lot of funds were invested in order to be recognized as a New Year's tourist destination.

On the other hand, Belgrade started with "green" or "eco-friendly" tours. Although it is still not massive, Belgrade is part of the international bicycle network, and there are even special cruisers that bring tourists for cycling along the Belgrade biking trails. In addition, there are also "sag way" tours, which are shorter (they include the lower and upper Kalemegdan with sights) and longer (they include the centre of the city with Knez Mihailova street, the Patriarchy building and the Belgrade port). In the case of river tours and in the case of "green" sightseeing tours of the city, it is necessary to organize a group, therefore, there are no regularly scheduled tours for individual tourists. On the other hand, when talking about the needs for additional MICE capacities, the TOB points to the fact, that an increasing number of hotel chains will open their facilities in Belgrade. The best example is that in 2018, the first hotel of the Hilton Corporation is opened in the very centre of the city. Prior to this corporation, "Intercontinental", "Starwood", "Marriot", "Falkensteiner", "Accor" and others are arriving to Belgrade. The current problems that the city 
International Conference on Research in Management \& Economics

Serbia | Belgrade | December 15-17, 2018

has, when it comes to this topic, are, according to TOB, the lack of congress and accommodation capacities in organizing large events.

\section{Benchmark Analysis - Project "Green Ljubljana" and its application on Belgrade}

In order to reward efforts for facing environmental challenges in European cities, the European Commission set up the European Green Capital award in 2010. In particular, the prize is awarded to a city that "has a consistent outcome on achieving high ecological criteria, and is committed to ambitious goals for further improvement of the environment and sustainable development, and that it can act as a model that inspires other cities and promotes good practices in all other European cities" (European Commission, 2018).

The city authorities of Ljubljana devoted themselves to the goal of creating a place where the local population will live healthier and ecologically organized, and to which the tourists will come in greater numbers contributing to the development of Ljubljana as a tourist destination. The development of Ljubljana as a "green" or ecologically and sustainably oriented destination, began with the "Vision of Ljubljana 2025" in which 93 projects worth at least 3 billion euros were defined (Mestna občina Ljubljana, 2018). As the two most important projects Mr. Koželj , the vice mayor of Ljubljana, pointed out the construction of three hydropower plants on the Sava River, which would shift the city to renewable energy sources, but also to the arrangement of a large Sava Park and the development of sports and recreational facilities. The second most important project, according to Mr. Koželj, was the reinforcement of the railway, bearing in mind that Ljubljana crosses two large railway corridors. This project is also related to the development of sustainable transport, which would, as such, solve the traffic problems of the city (Kos, 2008).

In order to get the status of the "green capital", Ljubljana had to make many changes in the city's existing functioning. In order to get closer to the ecological picture of Ljubljana, the official website of Green Ljubljana (Mestna občina Ljubljana, 2015) published data shows the extent to which the capital of Slovenia has advanced in terms of sustainable development, with particular emphasis on ecology and the use of renewable energy sources (Municipality of Ljubljana, 2015):

- 74\% of households are heated remotely and have natural gas distribution;

- Drinking water can be used completely without prior processing;

- The city center is now mostly for pedestrians and cyclists;

- $63 \%$ of the collected waste makes Ljubljana the leader in Europe;

- $542 \mathrm{~m} 2$ of public green areas per capita;

- 80 ha of newly maintained green areas;

- New green areas are made from degraded urban land;

- Ljubljana is on the list of the best cities for sustainable development. 
International Conference on Research in Management \& Economics

Serbia | Belgrade | December 15-17, 2018

It would be said that Belgrade, as well as Ljubljana at the time, needs a certain vision, supported by numerous projects that would make their move and contribute to sustainability. Nevertheless, when comparing Belgrade and Ljubljana, one should first point out some differences that should be taken into account when discussing the possibility that the Serbian capital moves in the same way as Ljubljana. First of all, Belgrade is a much larger city than Ljubljana, both in terms of population and area. Consequently, the frequency of traffic is much larger and more complex. In addition, when it started on such projects, Slovenia was largely a full member of the European Union, while Serbia is still on its way to becoming it. This is important because EU funds for the development and financing of projects are important, and Serbia, although the official candidate, cannot use these funds at full capacity. Belgrade could capitalize on the experience of Ljubljana in a way to make numerous projects with which it would apply to funds that would provide funding for financing. However, before that, much would have to be done on educating the population and explaining the need for a sustainable and ecological organization of the city. It is very important that such a concept be accepted by the local population so that it can be developed and implemented at full capacity.

As a multiple winner of the awards for sustainable tourism development and for the ecological organization of the city, Ljubljana can indeed represent a model that Belgrade could and should follow. First of all, Belgrade's city authorities should use good relations with Ljubljana officials to discuss projects that the largest Slovenian city realized and what are the effects of such changes. The transfer of experience is very important because it represents new knowledge and the opening of new horizons that can be used in the further development of the city as a tourist destination.

\section{Proposals and Discussion for the future Development of Belgrade as Tourist Destination}

In order to best define the most important tasks that Belgrade must do in order to develop in the future as a responsible and sustainable tourist destination, three main priorities are defined. These are concrete steps that must be implemented in order to make Belgrade a planned city and become a destination with better conditions for the development of the tourism industry. These priorities are:

- Priority I: Solving traffic problems in the city and improving the traffic infrastructure

- Priority II: Reconstruction and construction of tourist infrastructure

- Priority III: Improvement of ecological image and focus on environmental protection and town planning

Priority I: Solving traffic problems in the city and improving the traffic infrastructure 
International Conference on Research in Management \& Economics

Serbia | Belgrade | December 15-17, 2018

The main focus should be on relocating or limiting traffic to the city centre. In this way, conditions for several pedestrian zones would be created, and noise, pollution and traffic jams would be much smaller. As one of the most important steps towards a permanent solution to the problem of traffic in the city, it is necessary to completely complete the bypass around Belgrade, but also to disperse the traffic that is currently passing through the very centre of the city by building new roads that would serve as an additional bypass around the city centre. Expanding pedestrian zones and using environmentally friendly means of transport would be a positive step towards improving the ecological image of the city. In addition, several pedestrian zones in the city centre would be more attractive to tourists, and the level of noise and pollution in the city centre would be much smaller than now. By blocking or limiting traffic in the city center, the need for so many parking spaces would be reduced, and in the meantime, this would be economically good for the city, as more people would be using public transport. In order to do this, adequate conditions must be created. This implies the construction of the necessary infrastructure that would accept all traffic and enable a better flow around the city centre. Furthermore, it is necessary to continue with the reconstruction of the city roads, especially those that connect the most important tourist attractions. First of all it refers to "refreshment" and adaptation of roads leading to or located in tourist zones. By investing in quality rehabilitation of road infrastructure, Belgrade would get better quality roads, and pedestrians would be safer.

In addition, Belgrade's metro has been mentioned as the biggest project for decades. Construction of the metro network would enable better frequency and connection of all parts of the city, while at the same time reducing the concentration of motor vehicles in the city, which would reduce crowds and the number of motor vehicles on city roads. Finally, it is urgent that the authorities start solving the problem of unregistered taxi drivers. The largest concentration of such taxis is, logically, in the places where there are most tourists, such as airports, bus and train stations, and major tourist zones.

Priority II: Reconstruction and construction of tourist infrastructure

Quality tourism content is one of the basics of successful development and management of the tourist destination. In order to attract tourists, local authorities must create the conditions for utilizing the tourist potentials of the destinations and display them in the best way. This means good infrastructure, offering tourist objects with quality and unique contents, as well as new innovative contents that will enrich and strengthen the tourist offer. Such content must be based on the expectations and real needs of tourists and at the same time try to preserve the basic characteristics and culture of the tourist destination. The focus of the authorities should be on making the current tourism infrastructure fully accessible, especially those that have great cultural and historical significance and great importance in the promotion of Belgrade and Serbia. In addition to the reconstruction itself, it is necessary to carry out modernization that would 
International Conference on Research in Management \& Economics

Serbia | Belgrade | December 15-17, 2018

follow the modern tourist flows and needs of today's tourists. In this way, the promotion of Belgrade on the international tourist market would be meaningful and of higher quality, which would undoubtedly attract even more tourists.

In addition to completing the commenced reconstruction work, it is necessary to make an analysis and plans to bring other tourism attractions to a representative and usable level. Cultural and historical heritage, which is also one of the bearers of Belgrade's tourist offer, must be fully equipped to be used for tourist purposes of the city. In the first place, the expert commission should deal with this work, which would make an analysis of devastated objects that are of great cultural and historical significance for this city and country. Then it is necessary to find funds and invest them in a complete reconstruction, in order to present such objects in from of museum or tourist sites. Besides this, it is necessary to build a new tourist infrastructure that would not disturb the harmony, authenticity and tourist concept of the city. Such projects do not necessarily have to be great. The construction of a new viewpoint, free use of bicycles in tourist zones, theme hiking tours and similar projects can greatly enhance the quality of the tourist offer.

Priority III: Improvement of ecological image and focus on environmental protection and town planning

In order for the city to attract more tourists, besides tourist facilities and necessary infrastructure, it must also have adequate ecological conditions. For example, without the introduction of recycling and adequate containers for sorting waste, it is not possible to imagine successful waste management. And it's just something that currently ruins the city's image and affects the overall impression of tourists. This gives the city a label that it is "dirty" or "messy", and this kind of campaign undoes the great efforts the tourist organization invests in the promotion of the capital and state. Green oases, such as city parks or botanical gardens, need to be managed better, with significant promotion and better content. In this way, the city would demonstrate its ecological commitment; tourists would be much more attracted to the city, and the local population would live in a healthier environment. In addition, regular cleaning of streets, watering green areas, and more stringent control and prevention of the destruction of public areas; and property would change the image of the city for the better. Greater commitment to the use of renewable energy sources would improve the ecological image of the city and the country. The other parts of Serbia should also apply the same principle, hence the long-term economic benefit would be very significant. Given that Serbia does not have much practical experience with the use of renewable sources, it should apply examples of good practice from other countries, such as Slovenia, Austria or Germany.

In the process of deciding on the choice of the tourist destination toursits will visit, they pay more attention to the ecological segment, that is, to general treatment of environmental protection. Insufficient good rating in this segment can result in a large number of tourists who repel from 
International Conference on Research in Management \& Economics

Serbia | Belgrade | December 15-17, 2018

visiting a tourist destination, which means a smaller financial inflow for the local economy. In addition, the local population would have to benefit first and foremost from the correct and quality relationship to environmental principles, as this would bring healthier living conditions, a better environment in which they live, and the local government would also have financial benefits from recycling.

\section{Conclusion}

Tourist demand is influenced by many factors that contribute to the radical changes in the perception of tourism as an industry that records high rates of growth and progress. First of all, tourists are more and more interested in using their free time in a way to get to know the tourist destination culture and history. Preserving the tourist destination is the biggest precondition for tourists to come to this same destination again next year. This is one of the main initiators of the sustainable tourism development in tourist destinations concept emergence. First of all, nurturing and promoting local tourism products and services, as a basis for the survival of the authenticity of the destination. Then, encouraging the application of ecological norms in order to protect the natural resources, and finally, the development of jobs and the employment of the local population. This concept contributes to the stability of the tourist destination and opens the perspective for long-term development. It contributes to the economic benefits of the local population, which is one of the biggest features of the tourism industry. Also, this concept encourages reduction of adverse impacts on nature, preservation of the environment, as well as the use of renewable energy sources.

One of the conditions for a tourist destination to successfully and responsibly use its resources is to care for and preserve the environment and ecosystems. Raising the level of cleanliness and the care of green areas must be one of the priorities when it comes to further development of Belgrade as a tourist destination. It is precisely this segment where foreign tourists have the most objections. The regulation of municipal waste, the reduction of the level of exhaust gases and noise in the main tourist zones, the regulation of pedestrian zones, the reduction of traffic jams, cleaner streets, prevention of plotting graffiti on buildings facades are aspects that must be given special attention. The example of Ljubljana as a tourist destination that has made enormous progress in the area of sustainable and ecological management of a tourist destination is a model that Belgrade could follow. Taking into account all the differences that exist between these two main cities, the principle applied by Ljubljana, concerning the preparation of a large number of projects, including the relocation of traffic from the very centre of the city, is also applicable in Belgrade. Of course, all projects should be synchronized, with the ultimate goal of how Belgrade should function as a tourist destination. Undoubtedly, it takes a lot of effort to move this segment to a better one, and this is not possible without the clear and determined steps of the city 
International Conference on Research in Management \& Economics

Serbia | Belgrade | December 15-17, 2018

authorities to bring the state of the environment and better regulation of the city to a representative European level. This includes, among other things, the use of renewable energy sources, which would contribute to more efficient and longer-term use of existing resources in order to improve the ecological picture, reduce the emission of harmful gases and fuels.

In addition to improving the ecological image and appearance of the city, it is necessary to invest effort and resources in improving the tourist infrastructure. Every additional tourist component, regardless of its scope, which does not undermine the sustainability and city's authenticity, contributes to the enrichment and empowerment of the city's tourist offer. Also, accessible tourism is not something with which the capital of Serbia can be proud of. Access to a number of tourist attractions is not enabled for people with disabilities. Since TOB regularly monitors tourist facilities and tourist infrastructure, this is one of the areas that should be dealt with much more in the future, together with the relevant city authorities.

Finally, one of the main problems of the city concerns traffic regulation and traffic infrastructure. In the first place, a large amount of traffic consists of transit vehicles that are forced to enter the city because the bypass around the Serbian capital is not fully completed. Completion of this bypass must be a priority, and this will be the first step in solving the problems of transport. The second traffic problem is reflected in poor traffic infrastructure, primarily roads and railways. The rehabilitation of existing roads and the construction of new access roads and bridges that connect parts of the city are crucial for relieving the main city roads. In addition, the construction of new roads and bridges connecting other parts of the city would result in fewer motor vehicles at the access to the main city core, which is also the main tourist zone. This would open the possibility for opening several pedestrian zones that would additionally bring the city to tourists, but also contribute to a better ecological image of the tourist destination. One of the solutions for reducing the use of motor vehicles in the tourist zones of the city is to encourage the use of public transport, especially ecological buses that already exist in Belgrade. In addition, taxi transportation must be more regulated, especially in places where tourists get first contact with the city, such as airports, bus and train stations. A final solution to the traffic collapse and a longterm contribution to better traffic fluctuations is to build a metro system. The plan for the construction of the metro which has been delayed and changed for decades has to be realized in order for a large number of people to move more easily from one part of the city to another, including tourists, which would thus quickly and easily reach different tourist attractions, and at the same time use their time in a more efficient way.

The concept of sustainable development of a tourist destination is necessary in the capital of Serbia, because only in this way could local residents and tourists feel benefits. First of all, there will be improvement in city transport infrastructure and therefore better mobility. Then, the ecological orientation of the city would greatly contribute to a better image of the city. In addition, the use of renewable energy sources would bring the economic, which would increase 
International Conference on Research in Management \& Economics Serbia | Belgrade | December 15-17, 2018

the financing of new development projects. Involvement of local providers in the tourist offer would lead to the economic benefits of the local economy, as well as the population through new jobs and better working conditions. Tourists, on the other hand, would enjoy a more organised and cleaner city, with additional contents that best represent the history and culture of Belgrade. Such management of the tourist destination will provide better and more sophisticated touristic content, improved road infrastructure, cleaner and greener city zones, and most importantly, higher revenues and more tourists.

\section{References}

1. Bakić, O.: Mareting u turizmu. Univerzitet Singidunum, 2010

2. Butler, R. W.: Sustainable tourism: A state-of-the-art review. Tourism geographies, 1(1), 7-25, 1999

3. Cheia, G.: Ecotourism: Definition and concepts. Revista de turism-studii si cercetari in turism, 15, 56-60, 2013

4. Countryside Commission: Sustaining Rural Tourism. Cheltenham. Countryside Commission (CCP 483), 1995

5. Eber, S.: Beyond the Green Horizon: A Discussion Paper on Principles for Sustainable Tourism. WWF UK (World Wide Fund for Nature), 1992

6. European Comission: About EGCA. Retrived from: http://ec.europa.eu/environment/europeangreencapital/about-the-award/, 2018

7. European Comission: Winning Cities. Retrived from: European Green Capitals: http://ec.europa.eu/environment/europeangreencapital/winning-cities/, 2018.

8. Hetzer, W.: Environment, tourism, culture. UNNS, Reported Ecosphere, 1-3, 1965

9. Kos, D.: Vizija Ljubljane 2025. Retrived from: SiolNET.: https://siol.net/novice/slovenija/vizijaljubljane-2025-76462, 2008

10. Krivošejev, V.: Upravljanje baštinom i održivi turizam. Narodni muzej Valjevo, 2014

11. Mestna Občina Ljubljana: Dobrošli v Ljubljani. Retrived from: Zelena prestolnica Evrope 2017: http://www.zelenaljubljana.si/, 2015

12. Mestna občina Ljubljana: EUROPEAN GREEN CAPITAL 2016. Retrived from: Welcome to Ljubljana:

http://www.greenljubljana.com/, 2015

13. Mestna občina Ljubljana: Vizija Ljubljane 2025. Retrived from: https://www.ljubljana.si/sl/oljubljani/vizija-ljubljane-2025/, 2018

14. Swarbrooke, J.: Sustainable Tourism Management. Cabi, 1999

15. UNWTO: Definition. Retrived from: World Tourism Organization Sustainable Development of Tourism: http://sdt.unwto.org/content/about-us-5, 2017. 
International Conference on Research in Management \& Economics

Serbia | Belgrade | December 15-17, 2018

16. Vujić, T.: Upravljanje održivim razvojem turizma sa osvrtom na Republiku Srpsku. Univerzitet Sinergija,

2012 